\title{
Good Governance in Islamic Higher Education
}

\author{
Umar Sidiq ${ }^{1}$, Ju'subaidi $^{2}$ \\ State Islamic Institute (IAIN) Ponorogo, Jawa Timur, Indonesia ${ }^{1,2}$ \\ \{umarsidiqstainponorogo@gmail.com ${ }^{1}$, subaidi_6@yahoo. $\left.\mathrm{com}^{2}\right\}$
}

\begin{abstract}
At this time universities are under pressure from the government to show maximum results on funds that have been given by the government. Good university governance is now a hot topic. There are six things to consider in managing a good university: governance, academic program management, human resources, funding, college assets, and quality assurance, which is interesting to examine further how the efforts of state Islamic universities in developing good governance to create the quality of education especially postinstitutional transformation from the State Islamic Institute (IAIN) or State Islamic High School (STAIN) became State Islamic University (UIN).
\end{abstract}

Keywords: Good Governance, Islamic Higher Education.

\section{Introduction}

At this moment we have entered a new world order in a high-tech society. What exists today, due to the acceleration of science and technology, in the not-too-distant future it will quickly become "classic," out of date. At this moment what we think of as something up to date, then in the not-too-distant future it will become obsolete. This is what the contemporary calls it. An era in which everything becomes very temporary and rapidly changing and changing.

The advancement of information and communication technology has necessitated significant changes in many ways. In the context of learning, for example, the demand for the use of ICT in learning today becomes a necessity. Likewise in the management system, the demands of transparency and accountability of an educational institution are also of great importance.

This paper will try to examine the challenges of PTAIN in developing good governance in contemporary life. Either way, we agree to say that education is a fundamental thing that can not but be played to make a positive contribution in today's life.

There are several challenges that lie ahead for us in the future, namely internal and external challenges. First, in the era of globalization, the world is experiencing tremendous technological developments, including information technology, so that people will experience very fast mobility. As a result, people will experience drastic changes, which causes people to also experience imbalance. In addition, globalization will also facilitate the entry of new values. As soon as these new values flood the society so often, they can no longer be controlled adequately. Finally, members of society experience confusion and life imbalances.

Second, in the midst of rapid social change as a result of globalization, educational institutions and education systems must be strong supporters. Therefore, institutions and 
education systems must be able to function optimally. This system will provide adequate facilities and infrastructure, and also build and maintain the educators to have relevant competencies and have optimal economic welfare.

Third, the institution and the education system must be able to preserve the unique cultural values of Indonesian-ness. Cultural values can be a major factor in the transformation of education. A strong culture pervades the educational process will certainly be an important factor in the process towards the outcome of education that is characteristic of Indonesian-ness. It can also be an important element in the process of competition among nations in this global era.

\section{Result and discussion}

\subsection{Good Governance}

In a publication published by the Secretariat of the Partnership for Governance states that "good governance is a consensus reached by government, citizens and the private sector for the administration of country or state" [1]. That is, good governance is an agreement on state arrangements created jointly by governments, civil society, and the private sector. Therefore, for the realization of good governance, dialogue between important actors in the state is required. So that all parties feel to have the arrangement. Without the agreement born of this dialogue, prosperity will not be achieved because the political and economic aspirations of the people are blocked.

In terms of development administration, good governance is defined as follows: An overall institutional framework within wich its citizens are allowed to interact and transact freely, at the difference levels, to fulfill its political, economic and social aspirations. Good governance has three aspects:

- The ability of citizens to express views and access decision making freely;

- The capacity of the government agencies (both political and bureaucratic) to translate these views into realistic plans and to implement them cost effectively; and

- The ability of the citizens and institutions to compare what has been planned for what has been planned and what has been planned [2].

LAN \& BPKP (2000) argued that the meaning of good governance contains two understandings: First, the values that uphold the will/will of the people, and the values that can improve the ability of the people in achieving the goals (national) independence, sustainable development, and social justice. Second, the functional aspects of effective and efficient governance in the execution of its duties to achieve these objectives.

The OECD and the World Bank define good governance with a solid and responsible development of development management in line with democracy and efficient markets, avoidance of misallocation of scarce investment funds, and the prevention of corruption, both politically and administratively, run the budget discipline and the creation of legal and political frameworks for the growth of entrepreneurial activity [3]. UNDP defines good governance as a synergistic and constructive relationship between the state, the private sector, and society.

Also, other opinions as in the Government Regulation (PP) No. 101 of 2000. Formulated the definition of good governance, namely: governance that develops and applies the principles of professionalism, accountability, transparency, service excellence, democracy, efficiency, effectiveness, the supremacy of law and acceptable to the whole community. 
Kashi Nisjar (1997) in Domai (2001) argues that in general good governance contains the main elements consisting of accountability, transparency, openness, and the rule of law. Thus, basic elements of governance can be grouped into three categories:

- Country / Government: The conception of governance is essentially a state activity, but further than that it involves the private sector and civil society institutions.

- Private Sector: Private sector actors include private companies active in interactions in the market system, such as trade processing industry, banking, and cooperatives including informal sector activities.

- Civil Society: Community groups in the context of the state are essentially between or between the government and individuals, including both individuals and societal groups that interact socially, politically and economically [2].

Some opinions above have put forward what is meant by good governance, but in principle in good governance has a very deep meaning or meaning that is how the implementation or good management. This concept can apply to any organization, whether government, private or other community organizations formed for a noble cause.

\subsection{Implementation of Good Governance Principles}

In the Strategic Plan of the State Administration Institution 2000-2004, it is mentioned that there is a need for a new approach in the implementation of state and development that is directed in the realization of good governance namely: democratic governance, professional process upholds the rule of law and human rights, decentralistic, participatory, transparency, justice, clean and accountable, besides efficient, effective and oriented to improve nation competitiveness.

The key to understanding good governance is an understanding of the principles in it. Starting from these principles will get a benchmark performance of a government. The good or bad government can be assessed if it has touched with all elements of good governance principles. Recognizing the importance of this issue, the principles of good governance are parsed one by one as outlined below.

Next, the Ministry of Home Affairs of the Republic of Indonesia (2006) argued that the characteristics or principles that must be adhered to and developed in the practice of good governance, including:

- Society participation: All citizens have a say in decision-making, either directly or through legitimate representative bodies representing their interests. Such comprehensive participation is built on the freedom of assembly and expression of opinion, as well as the capacity to participate constructively.

- Enforcement of the Supremacy of Law: The legal framework should be fair and indiscriminate, including laws concerning human rights.

- Transparency is built on the basis of free information flow. All government processes, institutions, and information need to be accessible to interested parties, and the information available should be sufficient to be understood and monitored.

- Caring for Stakeholders: Institutions and the whole process of government should endeavor to serve all interested parties.

- Consensus-oriented: Good governance bridges different interests in order to build a comprehensive consensus on what is best for community groups, and where possible, consensus on policies and procedures.

- Equality: All citizens have the opportunity to improve or maintain their welfare. 
- Effectiveness and Efficiency: Governance processes and institutions produce results according to the needs of citizens and by using the resources that are as optimal as possible.

- Accountability: Decision makers in government, the private sector, and community organizations are accountable both to the public and to the agencies concerned. The forms of liability differ from one another depending on the type of organization concerned.

- Strategic Vision: Leaders and communities have a broad and far-reaching perspective on good governance and human development, as well as a sense of what is needed to make that progress happen. Also, they must also have an understanding of the historical, cultural and social complexities that form the basis for that perspective [4].

Characteristics of good governance above show a very potential dimension if applied in carrying out the work of an organization of any kind. It needs a real belief or trust from human resources who engineer and perform the basic tasks and functions of an organization of any kind by the attributes contained in the characteristics of good governance. But for that also required the ability of professionalism of potential quality.

\subsection{Implementation of Good Governance in PTI}

Marketing is a reality that is currently engulfing higher education. In the context of education management, this reality cannot be separated from the tendency of paradigm shifts from "government" to "governance." The world today has led to a "new world order" characterized by the reduction of state roles and the reinforcement of private and public roles. Under these conditions of corporate values, market values become very powerful.

Mok and Lo in his article entitled Marketization and Changing Governance in Higher Education: A Comparative Study states that at this time universities are under pressure from the government to show maximum results on funds that have been given by the government. Good university governance is at the moment a hot thing to talk about [5].

In the context of Indonesia, as in other developing countries, higher education is faced with three important challenges [6]:

- Improved quality, relevance, equity, efficiency, and governance.

- The position of higher education as a moral force to assist in directing democratization in society and social and political reforms.

- New challenges are arising from the increasing construction of knowledge economy, internationalization, and competition among countries.

The placement of the governance issue as the first order faced by Indonesia is something reasonable. Especially if we look at the reality faced by higher education in Indonesia. As reported by the Ministry of National Education that the quality of higher education in Indonesia is still low. This is for example when viewed from the low number of accredited higher education in Indonesia A. The study program in accredited A state university is less than $20 \%$, while in private universities and Islamic universities less than $10 \%$. As explained by the Ministry of National Education, accreditation is a tool to measure the minimum level of quality of higher education which in this case is implemented by BAN-PT [7].

That is why in its strategic plan the Directorate of Higher Education has determined the importance of organizational health creation to improve the quality of higher education. The health of a college organization is measured by applying the principles of good governance. There are six things to consider in managing a good college, that is 1 . Governance, 2. 
Management of academic programs, 3. Human Resources, 4. Funding, 5. College assets, and 6. Quality assurance.

Islamic universities as part of higher education institutions in Indonesia are of course also faced with the same challenges. Although Islamic higher education is handled by the Ministry of Religious Affairs, it is a unity in the education system in Indonesia. As explained by Nizam that since 1975-2003 in Indonesia there has been an increase in the number of residents who enroll in college, Islamic universities have contributed in increasing the number of citizens who register access to college [6].

Good management of good education should be an important thing to be considered, especially by looking at the contributions provided by Islamic universities that are not small in development. If not, of course, the deterioration of the quality of higher education in Indonesia is getting worse. If we make the ranking of Islamic universities in Indonesia as a benchmark to read the quality of higher education, then it should be admitted that Islamic universities (especially the country) are still left behind when compared with other universities. State Islamic universities have not been included in the list of top 10 university rankings that are taken into account.

This fact is interesting to examine further how the efforts of state Islamic universities in developing its good governance to develop the quality of education, especially postinstitutional transformation from the State Islamic Institute (IAIN) / College of Islamic Religion Affairs (STAIN) became the University Islamic State (UIN).

Since 2002, there has been a policy from the government to change the institutional status of IAIN Syarif Hidayatullah Jakarta to UIN Syarif Hidayatullah Jakarta. Institutional changes were then followed by another IAIN / STAIN namely IAIN Sunan Kalijaga Yogyakarta (2004), STAIN Malang (2004), IAIN Sunan Gunung Djati Bandung, IAIN Sultan Alauddin Makasar, and IAIN Sultan Syarif Kasim Riau. The emergence of the university policy of PTAIN is inseparable from efforts to respond to global trends that necessitate a college of any kind should compete with the competition. IAIN / STAIN institutional status is seen as too "stuffy" to accommodate developments, needs, and expectations of stakeholders.

Globalization has led to tough competition at the global level, in the context of higher education, forcing some countries to mobilize higher education that it runs to be globally oriented. Some countries in Asia such as South Korea, China, Singapore, Malaysia, and Thailand have made efforts to develop universities to become world-class universities. Institutional change from IAIN / STAIN to UIN is a strategic step to achieve the great ideals of PTAIN amid the changing of the global community.

Furthermore, Azra explained that the emergence of the idea of institutional change can not be separated from the issuance of UNESCO's "World Declaration on Higher Education for the Twenty-First Century: Vision and Action" which contains also the basic things since the mission and function of the College High; the role of ethics, autonomy, responsibility and anticipative functions of Higher Education; the formulation of the University's new vision; strengthening the participation and role of women in universities; development of science in higher education through research in the fields of social sciences, humanities, and science and technology, and dissemination of the results; development of long-term orientation of higher education based on relevance; strengthening university cooperation with the world of work, and analysis and anticipation of community needs; diversification of educational equity opportunities; innovative new approaches to education; empowering students as the main actors of Higher Education; development of qualitative evaluation of academic and administrative performance; anticipation of technological challenges; strengthening management and financing of universities; increased cooperation and alliances between 
universities with various stakeholders such as other scientific institutions, industry, society, etc $[8]$.

This simultaneously encourages a paradigm shift developed in national education based on three main points:

- Greater autonomy in management or autonomy. Autonomy not only in terms of managerial management but also in terms of determination or selection of curriculum to adjust the university to the world of work or market needs. Thus, universities function in addition to improving the quality of human resources (HR) who master the science and technology, social sciences and humanities, but also must develop the entire field of science through research and development (research and development).

- Greater accountability, not only in the context of the more responsible utilization of financial resources but also in the development of scholarship, educational content and programs organized. This accountability is not only to the government as educator or funder and other resources but also to the community and stakeholders who use and utilize University graduates and the result of developing various fields of knowledge.

- Greater quality assurance. This quality assurance can be done either through internal evaluation which is done continuously and continuously or through external evaluation, which is currently done by the National Accreditation Board (BAN), ISO, or similar institutions.

Looking at the above explanation, the important thing that is important to be realized and become a challenge for PTAIN after the policy of universalization is how the institution embodies Good University Governance (GUG).

\subsection{Some Offers Thought}

In this section will be described further some strategic steps that may be done PTAIN in responding to challenges in the contemporary era are [9]:

- The development of quality management by developing corporate management ideas in Islamic universities becomes unavoidable. Adoption of thoughts in corporate management in the management of higher education is expected to increase effectiveness, efficiency, and encourage the development of transparency and accountability of higher education as a public service institution.

- Leadership is reliable and visionary. This type of leader usually has the main characteristics: character, charismatic, competent and committed to the institution he leads. This leadership includes all the lines within a college. Such leadership is very important to become a driving force for the dynamics and development of an institution. In an era of requirements with very rapid changes such as today, the appearance of a reliable and visionary leader in a PTAIN cannot be negotiable. Leaders are reliable and visionary is expected to make major changes, as well as breakthroughs to PTAIN, can be in line with the needs of the era.

- In developing good university governance, the unavoidable is how PTAIN can develop cooperation. By building and expanding the network of cooperation (networking) is expected to limitations can be overcome. Being any idea of a college leader's idea, it would be meaningless if the college did not build a networking network. Especially in the current global era, building and expanding the network of cooperation is a necessity in the development of a college. Through this cooperation is expected to open the isolation of PTAIN amid increasingly global society and interconnected with each other. 
Also, with the cooperation of various institutional constraints will probably become easier to overcome.

- We are developing an inclusive and multicultural paradigm. The demand for openness and tolerance is irrevocable. The Messenger of Allah has taught Muslims about the principle of social integration to build a civil society. Islam refers to values, knowledge, and actions for its adherents to berta'aruf with other groups in different societies of religious, social and cultural background. Principles like this should we transform and be a paradigm in the development of PTAIN forward. In the development of good university, governance may be we will borrow various devices of thought from the outside which certainly does not conflict with the spirit and norms of Islam. Therefore, ultra-exclusive thinking models should be avoided. At least these things that should be considered in order to develop higher education in realizing good university governance in the midst of a very complex global challenge.

\section{Conclusion}

State College of Islamic Religion in the future will be confronted by a reality of intense competition. The competition not only comes from within the country but also from abroad. At such times, if a State Islamic College wants to exist and be reckoned with, besides doing the strategic steps as mentioned above must also be able to perform prima in accordance with the times among other universities.

\section{References}

[1] K. Prewitt, "Higher Education, Society, Government: Changing Dynamic," J. High. Educ. Africa, vol. 2, no. 1, 2004.

[2] S. Effendi, "Makalah: Membangun Budaya Birokrasi Untuk Good Governance," in Seminar Lokakarya Nasional Reformasi Birokrasi, 2005.

[3] R. Rinne and J. Koivula, "Changing Place of the University and a Clash of Values, the Entrepreneurial University in the European Knowledge Society: A Review of the Literature"," J. High. Educ. Manag. Policy, vol. 17, no. 3, 2005.

[4] K. Hardjasoemantri, "Makalah: Good Governance dalam Pembangunan Berkelanjutan di Indonesia," in Lokakarya Pembangunan Hukum Nasional ke VIII, 2003.

[5] K. H. Mok and Y. W. Lo, "The Impact of Neo-Liberalism on China"es Higher Education," J. Crit. Educ. Policy Stud., vol. 5, no. 1, 2007.

[6] Nizam, “Indonesia” dalam UNESCO. Bangkok: Unesco Asia, 2006.

[7] Depdiknas, Strategi Jangka Panjang Pendidikan Tinggi (HELTS) 2003-2010. Jakarta: Departemen Pendidikan Nasional, 2004.

[8] A. Azra, "IAIN di Tengah Perubahan Paradigma Baru Perguruan Tinggi," 2008. .

[9] M. I. Esha, 2 Tahun UIN Malang: Reorientasi Budaya Akademik Perguruan Tinggi. Malang: UIN-Malang Press, 2006. 